\title{
Regionalism, Political Risk and Capital Market Segmentation in International Asset Pricing
}

\author{
Richard Heaney \\ Australian National University \\ Vince Hooper \\ University of New South Wales
}

\begin{abstract}
This study examines the relationship between financial market segmentation and political risk. Financial economists have attributed market segmentation to factors such as foreign exchange risk, taxes, tariffs and capital controls whereas the influence of political risk has been largely ignored. It is discovered that markets are generally segmented on a regional basis. It is also found that there is a high correlation between political risk and capital market segmentation. However, some countries may appear to be integrated when not because their economies are affected by similar economic factors such as the price of commodities or level of economic development. These findings have profound implications for asset pricing. Multi-index models should be tested that incorporate a regional index, an economic development attribute, commodity factors and a political risk variable in order to price securities more effectively.
\end{abstract}

- JEL Classifications: F15, F36, G15, G12

- Key Words: Regionalism, Political Risk, Segmentation

\footnotetext{
*Corresponding address: Richard Heaney, Faculty of Economics and Commerce The Australian National University, Canberra 0200, Australia. Tel: +61-2-6125-4726, Fax: +61-2-6125-5005 E-mail: Richard.Heaney@anu.edu.au

Vince Hooper, School of Banking and Finance University of New South Wales, Sydney, Australia, Tel: +61-2-9385-5984, Fax: +61-2-9385-6347, E-mail: V.Hooper@unsw.edu.au (02001-Center for International Economics, Sejong Institution, All Rights Reserved.
} 


\section{Introduction}

This paper has two main purposes. First, a primary aim of this paper is to investigate the degree of market segmentation of financial markets by analysing the stock market returns of both developed and developing markets using cluster analysis. Cluster analysis is used because it is able to group stock market returns on the basis of similarity. Stock markets that have related return patterns have been those identified by previous studies to be more integrated. We see the emergence of a clustering of stock markets that is broadly on a regional basis. A further aim of this paper is to investigate the connection between political risk and market integration. The outcome of the research has profound implications for asset pricing models.

In a rarefied world of perfection in which markets are continually in equilibrium, access to information is costless and investors are purely rational then all of the worlds markets would be truly integrated. Under such conditions, capital would be free to traverse international frontiers and asset prices would conform to an internationalised version of the capital asset pricing model [Stulz (1981)]. All equilibriating price adjustments would be assumed to be instantaneous, either because changes are timeless or because all changes have been perfectly foreseen. However we do not live under such a quixotic paradigm. Frictions exist, which within an economic sense are market impurities that affect the way in which the laws of supply and demand interact. Market impurities prevent a general equilibrium from holding but create a series of partial equilibria for individual nations capital markets. The consequences of a disregard for market imperfections creating disequilibrium situations are such that justifiable doubt can be cast upon the theoretical and empirical application of the equilibrium-based tenets of the capital asset pricing model (CAPM). Within financial economics there is widespread ignorance of the impact of government policies as a major driver of market irregularities. It can be argued that all investment decisions are made within an arena of disequilibrium caused by the uncertainty associated with future government policy and the state of the nation [Kaldor (1972)]. The contribution of this paper to the literature is the discovery that financial market segmentation may indeed be due to political risk, that asset pricing models need to capture more fully government policies, incorporate the effects of regionalism and stage of economic development. It is also discovered that there is a spatial dimension associated with market segmentation. 
Within a domestic and international context, the capital asset pricing model has been found to be a poor prediction model for security's prices. While the theoretical derivation of the CAPM is solid, its impact within a real world of market imperfections is limited. Fama and French (1992) have found a weak association between beta and average returns. Further they find a statistically significant relationship between firm size, the ratio of market value to book value of assets and mean returns. Further, Roll (1977) has stressed that the market proxy may not be mean-variance efficient. Other frameworks have been developed to value securities, notably the international arbitrage pricing theory (IAPT) has emerged as a response to the inadequacies of the international asset pricing model (IAPM) [Solnik (1983)]. However, the IAPT remains very much in its infancy and empirical testing remains sketchy. However, a positive step in the international pricing of securities is the derivation of an IAPT that incorporates the effects of market imperfections [Fang (1992)]. Arbitrage pricing theory [Ross (1976)] is founded upon the assertion that a security's return is composed of an expected and an unexpected part ${ }^{1}$. A major critique of the arbitrage theory has been its empirical confirmation and the identification of factors driving returns of securities on an a priori and ex post basis ${ }^{2}$. Multi-index models have thus emerged as an extension to single index frameworks ${ }^{3}$ and an attempt to capture the influences of two or more factors upon a securities return ${ }^{4}$ which tend to be macroeconomic in nature. The results of this study suggest a grouping of stock market returns on a regional basis. This regional ordering of stock market returns corresponds with the ranking of political risk for each country concerned. It is reasonable to assume a regional impact in asset pricing because nations are more tightly bound by regional trade agreements, which inturn is driven by similar economic, social, political and cultural patterns. The concept of regionalism has emerged as a powerful force in geopolitical dynamics, trade theory and international finance. Game theoretical frameworks suggest that it is optimal for nation states to negotiate treaties on a regional basis rather than multilaterally [Cochinard (1995)]. Regionalism is not

\footnotetext{
${ }^{1}$ The expected return is common to all assets. The unexpected return contains a systematic and an unsystematic component. The systematic risk depends upon the sensitivities to a number of factors. A firms systematic risk is uncorrelated with its unsystematic risk factors.

${ }^{2}$ Principal component analysis with varimax rotation (factor analysis) has been used to test the APT model. A potential weakness of factor analysis is the interpretation of extracted factors, as well as the method of extraction.

${ }^{3}$ The Capital Asset Pricing Model (CAPM) is essentially a simple index model.

${ }^{4}$ The work on multi-index models emanated from the work of King (1966).
} 
only driven by geographic proximity of countries but similar cultural backgrounds and a complex interwoven mesh of trade, portfolio and foreign direct investment flows. The growing regionalism in the world today is viewed as a response to a cumbersome World Trade Organisation as an institution in the multilateral trading system and the repositioning of the super powers to a more polycentric stature. Regionalism is the fragmentation of over ambitious globalisation. As a result there is a high degree of economic interdependency nurtured between entities within regions which appears to be increasing over time. This leads to the idea that firms within them are affected often by similar exogenous shocks. Often idiosyncratic jolts tend to deepen and widen regional integration. This commonality and sense of belonging that prevails within regions may be reflected in related stock price movements. Financial economists have largely ignored the idea that stock markets may be driven more by regional factors than by global effects. Studies have tended to focus upon testing whether the international capital asset pricing model holds despite some of the criticisms levelled at the limits to its empirical verification. Multi-index models have not used a regional index. Some trading agreements in Asia such as the Association of South East Asian Nations (ASEAN) provide ample evidence of a strong regional relationship existing between nations stock exchanges relative to the world market portfolio ${ }^{5}$. This indicates that asset pricing frameworks should perhaps include a regional pricing index.

Capital markets are segmented due to a variety of factors such as exchange rate risk, different tax systems, capital controls, limits on foreign ownership and political risk. There are strong grounds to suggest that markets are neither completely segmented nor fully integrated as polarised extremes but exhibit characteristics of both [Choi and Rajan (1997)], and, display time-varying comovement with the world market portfolio [Bekaert and Harvey (1995)]. Market segmentation is brought about by a number of attributes which inhibit the theoretical CAPM from operating in a real world context [Jorion and Schwartz (1986), Hietala (1989), Gultekin, Gultekin and Penati (1989), Campbell and Hamoa (1992), Mittoo (1992), and Errunza, Losq and Padmanabhan, (1992)].

In particular, this study focuses on the effect that political risk has upon market segmentation because it is ultimately government policies that influence inter-

\footnotetext{
${ }^{5}$ Heaney and Hooper (1999) find evidence of a strong regional influence upon stock market returns in Association of South East Asian Nations (ASEAN) countries relative to Asia Pacific Economic Cooperation (APEC) countries.
} 
national capital flux. This line of enquiry has been ignored by financial economists due to the lack of quantification of political risk ${ }^{6}$. Traditional approaches to assessing political risk in economic decision-making have revolved around a case study approach. However, some information providers have created proxies for political uncertainty in the form of indices. A well acknowledged technique for measuring political risk is the Coplin and OLeary (1985) method. Political Risk Services (PRS) Inc. provides index data for the purposes of this study.

Political risk is the uncertainty associated with changes in government policy upon the cash flow patterns accruing to firms and investors. Political risk is best described as the probability of an event occurring over a given time period and is usually associated with major changes in government policies precipitated by dramatic episodes such as war, insurrection or political violence [Jodice (1985)]. Political Risk Services (PRS Inc.) captures political risk according to the attributes in Table 4. The convention is the higher the index, the lower the political risk. The rating ranges between 0 and 100 .

\section{Methodology}

The time period covered in this study is from $1^{\text {st }}$ Jan 1985 until $31^{\text {st }}$ December 1997 with the time interval being monthly. The stock market return data is sourced from the International Finance Corporation and Morgan Stanley for the same period. The data is monthly price relatives (natural logarithms) which includes a dividend adjustment.

This paper utilises cluster analysis to determine whether national stock markets are segmented on a regional basis. The advantage of using cluster analysis over other regression techniques is that it is a classification technique. In this study an attempt is made to group emerging stock markets by region. Traditional classification techniques involve assigning new observations to an established group whereas cluster analysis involves searching for "natural" groupings amongst objects and is thus a more inductive approach. Rather than regressing national stock market returns against a regional index, like the deductive approach adopted by Heaney and Hooper (1999), cluster analysis partitions cases into clusters of similar objects, i.e. similar behaviour in national stock market returns.

\footnotetext{
${ }^{6}$ Some authors have focussed upon the impact of government policies as a major creator of market imperfections within a multinational framework, e.g. Thomas Brewer (1992).
} 
Cluster analysis therefore has the advantage over regression analysis in the sense that regional and global stock market indices do not need to be constructed. One may argue that correlation could also be used to measure the degree of segmentation/correlation of a market. However, a key advantage to using cluster analysis is that it considers all returns simultaneously instead of pair by pair, as correlation is only able to do. We are thus able to develop a more comprehensive measure of stock market segmentation/integration in multi-dimensional space. In addition, cluster analysis enables us to group stock markets on the basis of similar volatility patterns unlike correlation analysis.

There are different methods for computing similarity measures between objects. A fundamental method is the shortest Euclidean distance method between two $p$ dimensional observations ${ }^{7}$. Cluster analysis is thus used to assign stock market returns, into relatively homogenous groups, i.e. regions. By the careful construction of a theoretical foundation, cluster analysis is used to objectively group the entities or countries using a hierarchical agglomeration algorithm. Aldenderfer and Blashfield (1984) argue that by using cluster analysis, a form of naïve empiricism is prevented. Its advantage also lies in the fact that it overcomes the problem of constructing a regional index because the cluster analysis is run with the returns of each stock market itself.

The cluster analysis method uses as an input the raw return data for both developed and emerging stock markets, and sequentially merges the most similar cases. The mergers of clusters are represented visually via a tree diagram called a dendogram [Figure 1]. This represents a hierarchical organisation of the relations between the data points. Although there are a number of variants of cluster analysis, the average linkage method proposed by Sokal and Michener (1958) was used because it computes the average of country returns, and joins the country to a cluster depending on this arithmetic average linkage. Its advantage lies in the fact that averaging returns across time compensates for the effects of the stochastic movement of emerging equity market return series.

Monthly stock market returns for thirty four countries are subjected to cluster analysis. The technique avoids making assumptions about data commonly associated with the time-series techniques of the financial economist. Cluster analysis also avoids the critiques associated with deduction and is an inductive

\footnotetext{
${ }^{7}$ For a discussion of clustering techniques, see Johnson and Wichern (1998).

${ }^{8}$ Initially there are as many clusters as objects. The most similar objects are first grouped and these initial groups are merged according to their similarities.
} 
Fig. 1. Dendrogram using Average Linkage (Within Group) and a Minowski Distance Measure.

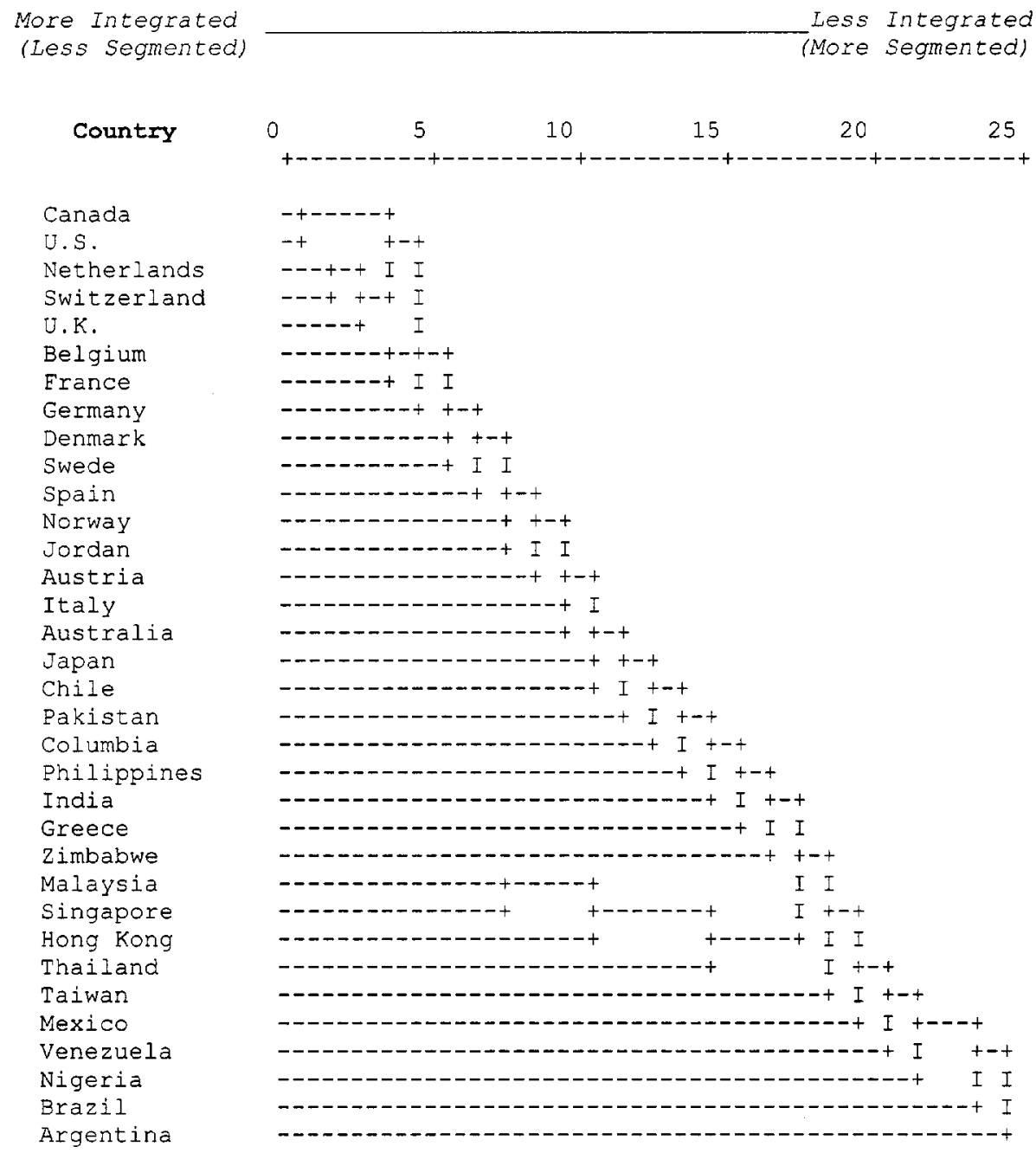

method. Though much less frequently used in the financial economics arena, cluster analysis is an extremely useful technique ${ }^{8}$. In this paper the average linkage method (within groups) ${ }^{9}$ is used as a clustering technique and the Minowski method is used as a distance measure ${ }^{10}$. The results of the cluster analysis are

${ }^{9}$ The average linkage method treats the distance between two clusters as the average distance between all pairs of items where one member of a pair belongs to each cluster.

${ }^{10}$ Minkowski distance is the $\mathrm{p}^{\text {th }}$ root of the sum of the absolute differences to the $\mathrm{p}^{\text {th }}$ power between the values for the items. This technique gives rise to a larger spread of distances between clusters. 
Table 2. Political Risk Index Rank and Cluster Rank

\begin{tabular}{|c|c|c|c|}
\hline Political Risk Rank & Country & Mean Index & Cluster Rank \\
\hline 1 & Switzerland & 92.23 & 4 \\
\hline 2 & Japan & 87.97 & 17 \\
\hline 3 & Netherlands & 87.57 & 3 \\
\hline 4 & Norway & 86.92 & 12 \\
\hline 5 & Germany & 86.59 & 8 \\
\hline 6 & Austria & 86.25 & 16 \\
\hline 7 & U.S. & 84.56 & 2 \\
\hline 8 & Sweden & 83.96 & 10 \\
\hline 9 & Denmark & 83.88 & 9 \\
\hline 10 & Canada & 83.67 & 1 \\
\hline 11 & Taiwan & 82.90 & 29 \\
\hline 12 & U.K. & 82.16 & 5 \\
\hline 13 & Singapore & 81.85 & 26 \\
\hline 14 & Belgium & 81.35 & 6 \\
\hline 15 & France & 80.82 & 7 \\
\hline 16 & Australia & 80.35 & 14 \\
\hline 17 & Italy & 77.40 & 15 \\
\hline 18 & Spain & 74.32 & 11 \\
\hline 19 & Hong Kong & 73.63 & 27 \\
\hline 20 & Malaysia & 72.52 & 25 \\
\hline 21 & Thailand & 67.21 & 28 \\
\hline 22 & Venezuela & 64.14 & 31 \\
\hline 23 & Mexico & 64.13 & 30 \\
\hline 24 & Greece & 63.15 & 23 \\
\hline 25 & Chile & 62.83 & 18 \\
\hline 26 & Colombia & 62.35 & 20 \\
\hline 27 & Brazil & 59.17 & 33 \\
\hline 28 & Jordan & 56.65 & 13 \\
\hline 29 & India & 54.89 & 22 \\
\hline 30 & Argentina & 53.35 & 34 \\
\hline 31 & Zimbabwe & 52.76 & 24 \\
\hline 32 & Philippines & 50.97 & 21 \\
\hline 33 & Nigeria & 49.22 & 32 \\
\hline 34 & Pakistan & 48.92 & 19 \\
\hline
\end{tabular}

shown in the form of a dendogram in Figure 1. The branches in the tree represent clusters. The branches merge at nodes whose positions along a distance (or similarity) axis indicate the level at which fusion take place and thus 
Table 3. Rank Correlation

\begin{tabular}{|llc|}
\hline Spearman's rho & Spearman's rho Correlation Coefficient & .646 \\
& Significance (2-tailed) & .000 \\
& Number of Ranks & 34 \\
\hline
\end{tabular}

Table 4. Critical Factors in the International Country Risk Guide Rating System

\begin{tabular}{|c|c|c|}
\hline Factor & Points & $\begin{array}{c}\% \text { of Individual } \\
\text { Index }\end{array}$ \\
\hline \multicolumn{3}{|l|}{ Political } \\
\hline Economic expectations versus reality & 12 & 12 \\
\hline Economic planning failures & 12 & 12 \\
\hline Political leadership & 12 & 12 \\
\hline External conflict & 10 & 10 \\
\hline Corruption in government & 6 & 6 \\
\hline Military in politics & 6 & 6 \\
\hline Organised religion in politics & 6 & 6 \\
\hline Law and order tradition & 6 & 6 \\
\hline Racial and national tensions & 6 & 6 \\
\hline Political terrorism & 6 & 6 \\
\hline Civil war & 6 & 6 \\
\hline Political party development & 6 & 6 \\
\hline Quality of bureaucracy & 6 & 6 \\
\hline Total Political Points & 100 & 100 \\
\hline \multicolumn{3}{|l|}{ Financial } \\
\hline Loan default or unfavourable loan restructuring & 10 & 20 \\
\hline Delayed payments of suppliers; credits & 10 & 20 \\
\hline Repudiation of contracts by governments & 10 & 20 \\
\hline Losses from exchange controls & 10 & 20 \\
\hline Expropriation of private investments & 10 & 20 \\
\hline Total Financial Points & 50 & 100 \\
\hline \multicolumn{3}{|l|}{ Economic } \\
\hline Inflation & 10 & 20 \\
\hline Debt service as a percentage of exports of goods and services & 10 & 20 \\
\hline International liquidity ratios & 5 & 10 \\
\hline Foreign trade collection experience & 5 & 10 \\
\hline Current account balance as a percentage of goods and services & 15 & 30 \\
\hline Parallel foreign exchange market indicators & 5 & 10 \\
\hline Total Economic Points & 50 & 100 \\
\hline Overall Points & 200 & \\
\hline
\end{tabular}

Note: Rounding errors could lead to some variation between individual percentage entries and the total percentages. 
can potentially be used as an integration or segmentation of capital markets measure.

\section{Results}

The dendogram shown in Figure 1 provides a ranking of countries according to strength of fusion ${ }^{11}$. The US and Canada form the closest amalgamation which can be explained by the close relationship that these two countries have through the North American Free Trade Agreement (NAFTA) and historical connections. The Netherlands and Switzerland form a cluster that then merges with the US, UK, Canada. Belgium, France, Germany, Denmark and Sweden then join these countries to form a larger grouping. Thus far, the clustering can be described as geographical proximity. The North American markets are highly integrated with the more advanced countries of the European Union. At first glance Jordan appears to be an exception. However, Jordan is fairly isolated from its nearest neighbours ${ }^{12}$. Jordan is a party to the Euro-Mediterranean Agreement (EMA) which has essentially meant free trade with Europe [Djankov and Hoekman (1996)], hence the grouping with European countries stock market returns. Australia is grouped with European countries. Chile ranks quite highly in its level of integration relative to other South American countries that may be due to its higher level of economic advancement. There has been speculation that Chile may be the fourth member of NAFTA [von Furstenberg (1997), Harrison, Rutherford and Tarr (1997)]. It is difficult to place countries such as Pakistan, Columbia, Philippines and India except that these countries have similar export industries such as agriculture and textile industries and are at similar stages of economic development and openness, and less integrated. Greece is also an anomaly. However, Greece has been relatively isolated from European countries and more integrated with the Balkan states, is one of the poorest countries within the European Union (EU) in terms of per capita income and has restricted capital flow and focus has tended to be upon agriculture [Pereira (1997)]. Singapore, Malaysia,

\footnotetext{
${ }^{11}$ The solution is robust to hierarchical clustering algorithm which indicates that countries are correctly matched to a cluster.

${ }^{12}$ Israel, the West Bank and Gaza are more economically integrated than with Jordan according to Arnon and Spivak (1996).

${ }^{13}$ ASEAN was founded in 1967 and represents a restrictive form of economic alliance. Hong Kong although not a member of ASEAN has a heavy Asian focus, especially on China in terms of its economic linkages. The major trading partners of ASEAN countries are China, India, Pakistan and Russia.
} 
Thailand, Hong Kong and Thailand are clustered but are integrated to a higher extent than other countries ranked below them. They show as much integration with each other as European countries exhibit ${ }^{13}$. The remaining countries are generally Latin American countries where economic integration with the world economy has been traditionally low. The influence of China upon South East and North Asian countries cannot be ignored [Jia and Muraoka (1996)]. The least integrated country appears to be Argentina. South America has been slow to implement regional trade accords [Burki, Perry and Calvo (1998)]. Mexico, Venezuela, Brazil and Argentina are grouped on a regional basis and perhaps because of their dependence upon oil as an export commodity [Karl (1997)]. Note that Nigeria, a major oil exporter is also grouped with South American countries. They would be similarly affected by outside shocks such as a change in the oil price without being necessarily linked economically. The ranking of political risk indices and a countrys cluster ranking is shown in Table 2. The rank correlation coefficients between political risk and market segmentation is shown in Table 3. There is a strong relationship between political risk and ranking of cluster membership. This suggests that political risk is a major driver of capital market segmentation.

\section{Conclusion}

This study has discovered that financial markets appear to be segmented on broadly a regional basis when subjected to a cluster analysis. There is a close relationship between the membership of a country to a cluster and its political risk rating. In this regard, the study has perhaps captured the driver of segmentation of capital markets, government policies and a nations stability. The results are powerful in the sense that traditional asset pricing of international securities has not adequately impounded the uncertainty that surrounds policy change by governments. However, countries may not only be segmented on a regional basis. Some economies may be driven by common factors such as similar levels of economic development, commodity prices or a lack of economic openness. This paper, although to a large extent exploratory, does provide financial economists with directions on what may be useful to contain as variables in constructing multi-index asset pricing frameworks.

Finally, the authors have a preference for multi-index models as a way forward because the assumptions upon which the capital asset pricing model are founded 
are highly impractical in a world where market impurities are ubiquitous and information flows are distorted. A positive step forward in asset pricing would be to incorporate market imperfections and macroeconomic variables into an internationalised version of the arbitrage pricing theory which would allow financial economists to escape from the intellectual straight-jacket that general equilibrium based asset pricing models impose. The authors are interested in further research that may uncover the utility of stock market data as proxies for evaluating country-specific socio-economic, cultural and political dynamic phenomenon. This may enable the finance discipline to evolve beyond its often constraining boundaries.

Date accepted: January 2001

\section{References}

Aldenderfer, M. S. and Blashfield, R. K. (1984), Cluster Analysis, Sage University Paper: Quantitative Applications in the Social Sciences, 44.

Arnon, A. and Spivak, A. (1996), "Monetary Integration between the Israeli, Jordanian and Palestinian Economies", Weltwirtschaftliches Archiv, 132(2), 259-77.

Bekaert, G. and Harvey, C. R. (1995), “Time-Varying World Market Integration”, Journal of Finance, 50(2), 403-444.

Brewer, T. L. (1992), "Effects of Government Policies on Foreign Direct Investment as a Strategic Choice of Firms: An Expansion of Internalization Theory", International Trade Journal, 7(1), 111-29.

Burki, S. J., Perry, G. E. and Calvo, S. (1998), “Trade: Towards open regionalism: Proceedings of a conference held in Montevideo, Uruguay", Annual World Bank Conference on Development in Latin America and the Caribbean, 1997: Latin American and Caribbean Studies: Proceedings series. Washington, D.C.: World Bank, 277.

Campbell, J. Y. and Hamao, Y. (1992), "Predictable Equity Returns in the United States and Japan: A Study of Long-Term Capital Market Integration", Journal of Finance, 47(1), 43-69.

Choi, J. J. and Rajan, M. (1997), “A Joint Test of Market Segmentation and Exchange Risk Factor in International Capital Markets", Journal of International Business Studies, 28(1), 29-49.

Cochinard, S. (1995), "L'Evolution du Concept de Coalition en Theorie des Jeux. (The Coalition Concept in Game Theory)", Revue d'Economie Politique, 105(4), 633-55.

Coplin, W. D. and O'Leary, M. K. (1985), “The World Political Risk Forecasting Service", in: T.L. Brewer, ed., Political Risks in International Business, Praeger, New York. 
Djankov, S. and Hoekman, B. (1996), "Effective Protection and Investment Incentives in Egypt and Jordan During Transition to Free Trade with Europe", Centre for Economic Policy Research, Discussion Paper: 1415, June, 20.

Errunza, V., Losq, E., Padmanabhan, P. (1992), “Tests of Integration, Mild Segmentation and Segmentation Hypotheses", Journal of Banking and Finance, 16(5), 949-72.

Fama, E. and French, K. (1992), "The Cross-Section of Expected Stock Returns", Journal of Finance, 47(2), 427-65.

Fang, H. (1992), "International Arbitrage Pricing Theory with Market Imperfections: A Note", Journal of International Financial Markets, Institutions \& Money, 2(1), 47-56.

Gultekin, M. N., Gultekin, B. N. and Penati, A. (1989), "Capital Controls and International Capital market Segmentation: The Evidence from the Japanese and American Equity markets", Journal of Finance, 44(4), 849-869.

Harrison, G. W., Rutherford, T. F. and Tarr, D. G. (1997), “Opciones de Politica Comercial para Chile: Una Evaluacion Cuantitativa”, Cuadernos de Economia, 34(102), August, 101-37.

Heaney, R. and Hooper, V. (1999), "World, Regional and Political Risk Influences Upon Asia Pacific Equity Market Returns”, Australian Journal of Management, 24(2), 131142.

Hietala, P. T. (1989), “Asset Pricing in Partially Segmented Markets: Evidence from the Finnish Market”, Journal of Finance, 44(3), 697-718.

Jia, L. and Muraoka, T. (1996) Chinas Regional Economy in the Asia Pacific Regional Context, Rivista Internazionale di Scienze Economiche e Commerciali, 43(3), JulySeptember, 695-715.

Jodice, D. (1985), Political Risk Assessment: An Annotated Biography, Greenwood Press, Westport.

Jorion, P. and E. Schwartz, 1986, Integration vs. Segmentation in the Canadian Equity Market, Journal of Finance, 41(3), 603-13.

Johnson, R. A. and Wichern, D. W. (1998), Applied Multivariate Statistical Analysis, Prentice Hall, New Jersey.

Kaldor, N. (1972), “The Irrelevance of Equilibrium Economics”, Economic Journal, 82, December, 1237-1255.

Karl, T. L. (1997), “The Paradox of Plenty: Oil Booms and Petro-States", Studies in International Political Economy, 26, 342.

King, B. F. (1966), "Market and Industry Factors in Stock Price Behaviour", Journal of Business, January.

Mittoo, U. R. (1992), “Additional Evidence on Integration in the Canadian Equity Market", Journal of Finance, 47(5), 2035-53.

Pereira, A. M. (1997), "Development Policies in the EU: An International Comparison", Review of Development Economics, 1(2), June, 219-35.

Roll, R. (1977), “A Critique of Asset Pricing Theorys Tests: Part I: On Past and Potential Testability of the Theory", Journal of Financial Economics, 4(2), 129-176.

Ross, S. (1976), “The Arbitrage Theory of Capital Asset Pricing”, Journal of Economic 
Theory, 13(3), 341-60.

Sokal, R. and Michener, C. D. (1958), “A Statistical Method for Evaluating Systematic Relationships", University of Kansas Scientific Bulletin, 38, 1409-1438.

Solnik, B. (1983), "International Arbitrage Pricing Theory", Journal of Finance, 38(2), 449-57.

Stulz, R. (1981), “A Model of International Asset Pricing”, Journal of Financial Economics, 9(4), 383-406.

Von Furstenberg, G. M. (1997), The Banking and Financial Structure in the NAFTA Countries and Chile, Kluwer Academic, Boston; Dordrecht and London, 266. 